\title{
Pal Beach Tourism Development in Marinsow Village, North Minahasa Regency
}

\author{
Seska M. H. Mengko*, Pearl L. Wenas, Selvie R. Kalele \\ Departement of Tourism, State Polytechnic of Manado, Manado, Indonesia
}

\begin{abstract}
This study aims to identify the potential of Pal Beach tourism attraction, identify individual infrastructure and attraction facilities of Pal Beach, and reviewing tourism development of Pal Beach. This research was conducted in the village of Marinsouw, North Minahasa Regency for six months from April to October 2016. This study used a qualitative description. The results on the development of Pal beach tourism object showed that 1). Accessibility (affordability); driveway access to the Pal coastal resorts is damaged and needs to be repaired by resurfacing and widening the road. 2). Attraction; in this case is the cultural attraction that is religious tourism such as Tulude culture which is a tradition of rural communities of Marinsouw on every January $31^{\text {st }}$ should be developed and packaged in a tour package to attract foreign or domestic tourists to more frequently come to the village of Marinsouw and the Pal beach. 3) Amenities (facilities/comfort); there is a needs to build an inn or a cottage accommodation in Pal coastal region, tourism information facilities are necessary to hold art and culture of Marinsouw rural communities, souvenir shops, restaurants, sanitation of toilet, and recreation attraction for entertainment. 4). Ancillary Services (institutional services and promotions); need to be made marketing and promotional information systems of Pal beach tourism with the full support of the Government in promoting Pal beach attraction. Recommendation of this study, the first for North Minahasa Regency Tourism Office is: a). North Minahasa Regency Government through the Department of Tourism and Cultural needs to make a MoU with the state-owned enterprises to build Pal beach attraction. It is a pity if the potential of Pal beach is not developed and promoted as a tourism destination area; b). Need to restructure and mapping the Pal coastal tourist area unit. c). Attract investors to build tourism supporting facilities such as accommodation, tourism information center, souvenir shops, special attraction; d). Prepare human resources in the field of hospitality and tourism attractions to manage Pal beach; e). Increase counseling and training in preparing resources for the development of Pal beach tourism object; and the second for Marinsouw Rural Community is: a). Preserving cultural customs Tulude as a tourist attraction to be promoted; b. Make Masamper dance attractions on certain days in Pal coastal resort; c). Manage local products such as Goroho banana chips, cassava chips, skills for making plastic flower stalks as typical souvenir from Marinsouw village to raise the family economy; d). Raise awareness in maintaining the security and cleanliness around Pal coastal resorts.
\end{abstract}

Keywords: Attractions, Development, Pal Beach.

\section{INTRODUCTION}

The success of the government in promoting North Sulawesi as one of tourism destinations is evidenced by the large number of foreign tourists who are dominated by Chinese travelers. Press Release Data from North Sulawesi No. $65 / 10 / 71 /$ Th.X, October $3^{\text {rd }} 2016$ [1], tourism in North Sulawesi experienced rapid growth in August. Total tourists who came to North Sulawesi through the entrance to Sam Ratulangi airport in August 2016 were as many as 7,904 people, an increase of $2.96 \%$ compared to July 2016 amounted to 7,677 people. When compared with foreign tourists who visited in the previous year as many as 2,247 people in August 2015 , foreign tourist visits increased by $251.76 \%$ (Table 1). This proves that tourism in North

${ }^{*}$ Correspondence address:

Seska M.H. Mengko

Email: seskamengko@gmail.com

Address: State Polytechnic of Manado, Mapanget District, Manado 95252.
Sulawesi has become known at the international level.

Table 1. Foreign Tourist to North Sulawesi in August 2015

\begin{tabular}{ccc}
\hline Country & Number of Visitors & Percentage (\%) \\
\hline China & 6,455 & 81.67 \\
Singapore & 229 & 2.90 \\
Germany & 154 & 1.95 \\
Japan & 130 & 1.64 \\
Hong Kong & 129 & 1.63 \\
USA & 115 & 1.45 \\
Netherlands & 85 & 1.08 \\
UK & 80 & 1.01 \\
Australia & 72 & 0.91 \\
Malaysia & 51 & 0.65
\end{tabular}

Source: Statistic Center of North Sulawesi [1]

The increasing number of tourists coming to Manado, North Sulawesi should be followed with the development of adequate infrastructure and tourism facilities needed by tourists. It also need public awareness in conserving nature tourism as a form of support for the government's program in developing tourism in the region. It must be improved as a result of tourism itself and 
improving and enhance the economy, especially the local economy.

Pal beach in the village of Marinsouw, East Likupang District, North Minahasa Regency, has the charm of a very beautiful beach and the main attraction for every visitor who comes. Its name is unfamiliar because this exotic beach is still relatively new, having been opened to the public only in 2015. Since February 2015, the beach was crowded with hundreds of visitors who come from various regions in North Sulawesi. The beauty of white sand is an attraction for local tourists to come to visit $\mathrm{Pal}$ beach. It is not exaggerating that a few visitors call this beach heaven, new hidden beach in North Sulawesi. Even some visitors compare this beach to Kuta beach in Bali. Based on the recognition of Marinsow villagers that guard the Pal Beach, on weekends or holidays, Pal Beach can be visited by about 5,000 people whereas, formerly Pal beach was deserted from visitors except the villagers themselves.

From observations and interviews with local people, we found that the number of peak crowds were in the month of February 2015 until October 2015. In November 2015, the number of visitor began to decline gradually until the beach was devoid of visitors in August 2016. If the number visitors could reach 5,000 persons a day now there are only 10 to 30 people a day on weekdays. On the holiday, Pal beach is visited by about 300 people coming from North Sulawesi region who want to travel with family, friends or spiritual travel. The people's income decreased drastically. Usually they got 3-7 million a day, which means an increase in people's income by $80 \%$ decreased to 300 thousand a day.

Entrance retribution of $\mathrm{Pal}$ beach is managed by the village government to pay janitors and coastal security. Retribution issued is Rp. 10,000 per car and Rp. 5,000 per motorcycle. Retribution of entrance to $\mathrm{Pal}$ beach is a contribution to the local revenue $(P A D)$ managed by the village government of Marinsouw beginning in February 2015. Each week, the number of vehicles increased from 1000-3000 vehicles with total revenues of about 10-12 million spent for cleanliness and security around the Pal beach. From 2015 until February 2016, the number of visitors decline gradually so that the effect on the amount of revenue from the retribution of entry was about 1-2 million per week.

The decline in the number of visitors to Pal beach occurs because to go to the Pal beach resort, the road about $2.5 \mathrm{~km}$ is severely damaged and stony causing long traffic jams when more visitors come. The local community regret that it has not received any attention from the government of North Minahasa Regency. Infrastructure of tourism is all the facilities that allow the tourism facilities to survive and thrive thus it can provide services to satisfy the diverse needs of travelers [2]. The amenities include a road or driveway to the attractions. Besides the lack of tourism attractions as well as the availability of supporting facilities such as places for selling tourist souvenirs, tourism information facilities and so forth.

A tourism destination, should cover five important elements to allow tourists to feel satisfied in enjoying the tour which includes: 1) Attractions; covering the natural beauty, climate and weather, culture, history, ethnicity or tribal nature, and accessibility to specific place. 2) Facility. 3) Infrastructure; include the system irrigation/water, supply of electricity and energy, communication networks, drainage system, health services, and 4). Transport and 5). Hospitality [3].

Pal coastal tourism development is expected to increase the return visits of local and foreign tourists in order to revive the economy of rural communities of Marinsouw as tourism players around Pal coastal resorts. In this case, the government should immediately go to the beach to improve access to Pal, so the beach resort has greater appeal, so it will able to bring back more visitors, thus have a direct impact on local revenue $(P A D)$. Development as a strategy used to promote and improve the condition of an object of tourism and attractions that can be visited by tourists as well as to provide benefits to the community around objects and attractions as well as for the government [4]. The aim of this study is to identify the potential of Pal Beach, identify the facilities and infrastructure in the area of Pal Beach and assess the potential development of Pal Beach attraction.

\section{RESEARCH METHOD}

This study was conducted for six months from May to October 2016 in Marinsouw Village, Regency of North Minahasa. This study used a qualitative descriptive analysis technique to give review or interpretation of obtained data so that it becomes clearer and more meaningful. The process of data analysis performed in this study using a model developed by Miles and Huberman [3], better known as an interactive model. This analysis model through the following processes: 
1). data that have been collected are reduced in the form of the main points of the research findings that are relevant to the research, and then presented in a narrative, 2 ). Data reduction and data presentation are the two components of the analysis performed in conjunction with the data collection process, 3 ). The next process is the conclusion, carried out during the collection process, which is done after the data are presented, described, then given meaning by logical interpretation.

This analysis is a process of interaction between the three components of the analysis with data collection, and is a cyclical process until the research activities completed. Stages of the research processes can be seen in Figure 1 . Analysis of tourism development is based on the concept of Pal beach 4A, namely the Attraction, Accessibility (affordability), Amenities (or comfort), and Ancillary services (institutional services and promotions) [4].

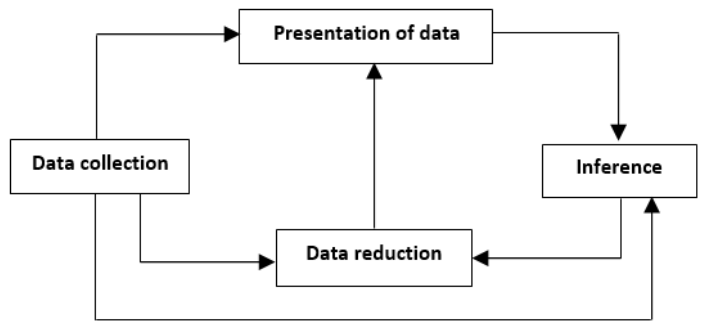

Figure 1. Model Interactive Analysis [3]

\section{RESULT AND DISCUSSION}

Identification on Potential Attractions of Pal Beach

As can be seen in Figure 2, Pal beach which is located in the village of Marinsouw, Likupang East District, North Minahasa Regency has incredible beauty beach scenery. This beach name sounds quite unfamiliar, but its beauty is unquestionable.

When entering this beach, tourists will be welcomed with a string of gorgeous white sand that extends approximately 100 meters on the shoreline. It is coupled with the cool air because of the shady trees growing around the beach. The crystal clear sea water adds its own charm. No garbage or the like as far as the eye sight. The waves on the beach looks like a roll of white paper. Some visitors seemed stunned witness the beauty of God's creation. The conditions are like this seems to imply that this beach location has not been touched by human. It does not seem too much when there are few visitors who call this Pal coast a new hidden 'heaven' beach in North Sulawesi and even some visitors compare this beach to Kuta beach in Bali [5]. Since the position of this beach faces east and is supported with a beautiful panorama, the beauty of the sunrise on the beach will look more beautiful for those who like to hunt sunrise (Fig. 3).

In addition to the stunning beaches, Pal beach is also home to the turtles that are about to spawn in the heap of white sand. After hatching, the tiny turtles will emerge from the sand and walk towards the beach. These turtles will be maintained as one tourism potential of Pal beach (Fig. 4).

Pal beach has a natural charm of underwater beauty of colorful coral and small fish in various forms to make Pal beach one of the attractions for tourists who have a hobby of diving. Besides, there is a Burung Cape round Pal beach. There are many government's plan for mangroves and the Marinsouw village to be developed; as mangrove tourism attractions that can support Pal beach.

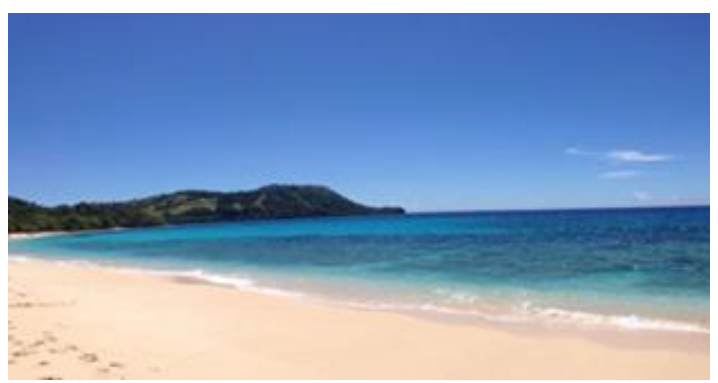

Figure 2. Pal Beach (source: Telusur Indonesia 2015)

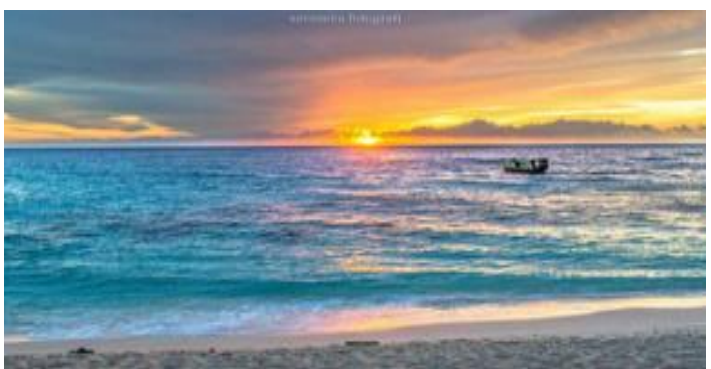

Figure 3. Sunrise at Pal Beach (source: Telusur Indonesia 2015)

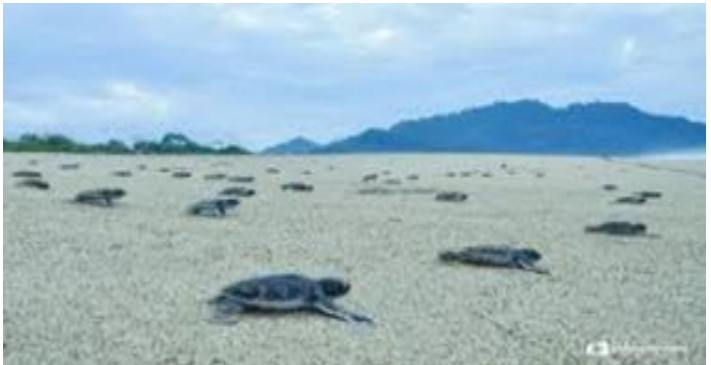

Figure 4. Turtle Hatchling at Pal Beach (source: Telusur Indonesia 2015 


\section{Identification of Infrastructure and Facilities in Pal Beach}

One of the objects in tourism marketing deals with the infrastructure that supporting the tour. Among others are Recreative and Sportive Plan, and Residential Tourist Plan [6].

\section{Restaurant}

Restaurant is one of the important supporting facilities for tourism activities. The restaurant in the area of Pal beach has food stalls made of bamboo with a simple shape that does not provide the main menu foods such as rice and side dishes, but only provides snacks such as fried bananas, boiled instant noodles, coffee, and a variety of cold drinks and snacks. There are only seven stalls in Pal beach area (Fig. 5).

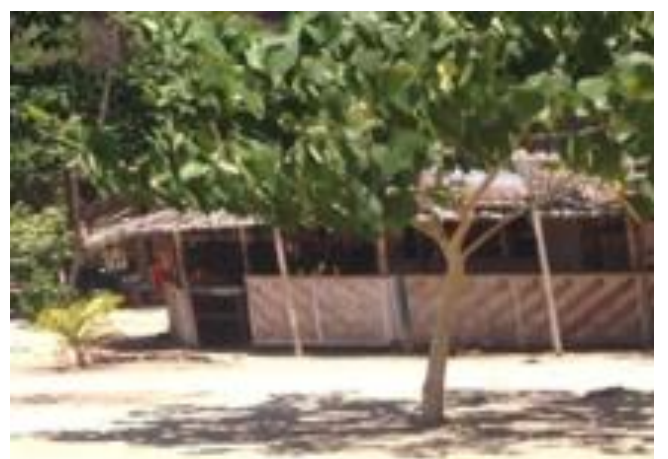

a

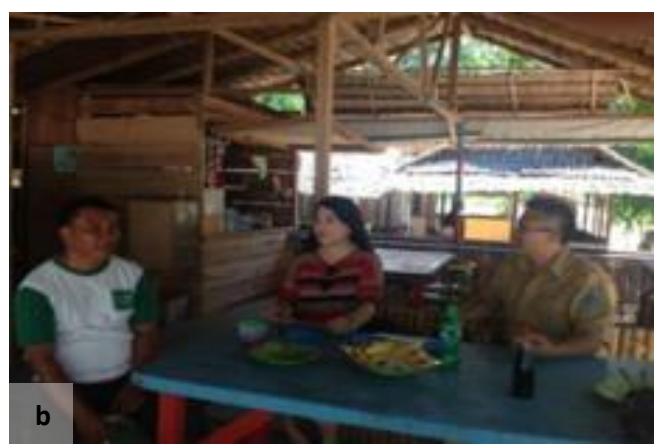

Figure 5. Public Restourant at Pal Beach. a) the bamboo stalls, b) inside the bamboo stall. (source: personal documentation)

\section{Souvenir Sales Sites}

In a well-developed tourist area, there are many places selling souvenirs for tourist. As with Pal beach, because the attraction is still relatively new, it does not provide souvenir sales facilities in Pal coastal resort yet. However, local products from Marinsouw village such as Goroho bananas can be found at food stalls around the tourism area. Other local products such as banana chips, cassava chips are not yet processed by the local community to serve as an souvenir for visitors because of the poor knowledge of the local product package.

\section{Entertainment Facility}

Pal beach is a tourism attraction that has a beautiful beach which is very charming. A stretch of white sand and crystal clear sea water into one of the amusement rides for visitors to bathe and swim at the beach, also with the sun while enjoying the natural beauty of Pal beach (Fig. 6).

Aside from being a family recreation place, Pal beach also has water sport facilities such as banana boat and donut boat with the rental price of Rp. 25,000 per person. Visitors can take advantage of a banana boat and donut boat to tour around $\mathrm{Pal}$ beach for 30 minutes with $\mathrm{a}$ speed adapted to the demand of visitors as shown in Figure 7.

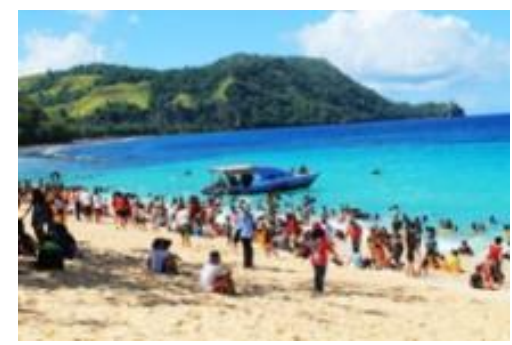

Figure 6. Pal Beach for Family Recreation (source: Telusur Indonesia 2015)

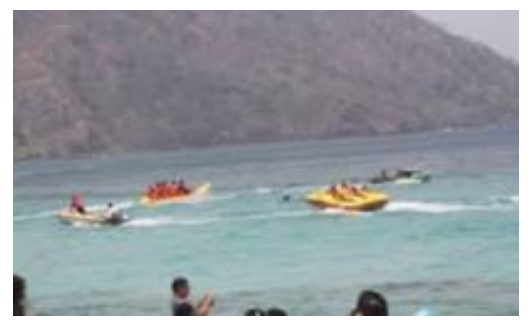

Figure 7. Water sport in Pal Beach (source: Telusur Indonesia 2015)

\section{Clean Water Supply}

Clean water in Pal coastal region is drilled well water taken from the village area. The water transported with a pickup and put into $600 \mathrm{~L}$ and $1100 \mathrm{~L}$ barrels. Each $600 \mathrm{~L}$ sized water barrel is charged Rp. 50,000 and and each $110 \mathrm{~L}$ sized water barrel is charged Rp. 85,000. Clean water is used for the needs of cooking, rinsing and toilet. Need for clean water in Pal coastal areas is provided in accordance with the number of visitors. Currently, Pal beach is crowded, requiring more than one barrel with the size of $600 \mathrm{~L}$.

\section{Sanitation Needs}

Facilities for sanitary purposes such as public toilets, provided by the food stall owners in Pal coastal area with a total of 14 toilets. Visitors 
who use the toilet are charged Rp. 2000 for urination and Rp. 5000 for defecation. In addition to public toilets, there are rented rinsing facilities also available for visitors who bathe on the beach at a price of Rp. 5,000 for each bucket. Public toilet facilities and the rising place are still far from the standard of tourism because it is built using the sack or tarp as a cover walls or rooms. But some are already built semi permanently.

\section{Trash can}

Pal beach areas provide 120 bins. It can be seen from the cleanliness that is displayed when you enter Pal coastal areas you will see no garbage spread, as janitors are paid by the village government. The payment using the fund taken from the retribution in $\mathrm{Pal}$ beach area with awareness and full responsibility to maintain the cleanliness of the beach and the coastal area.

\section{Access Road}

The entrance to Pal beach area is still inadequate, despite being paved with paving standards. But in a few months later, it is found a lot of broken asphalt resulting in holley and rocky road (Fig. 8). This is an obstacle for visitors who have a desire to enjoy the beauty of the Pal beach. Many visitors complained reasonably about access to the Pal beach which is $2.5 \mathrm{~km}$ from the village. During holiday season and national holidays, Pal beach is crowded causing long traffic jam when you enter Pal beach area. It is also the cause of the declining number of visitors who come to the Pal beach.

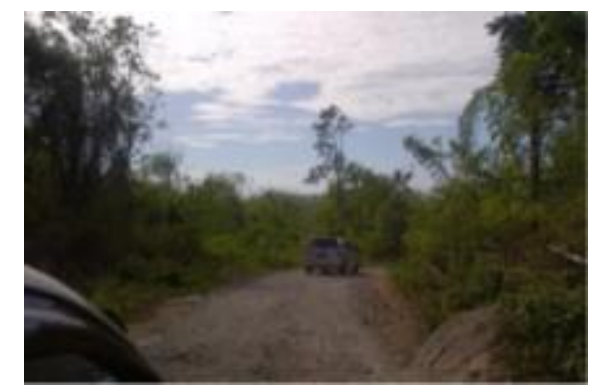

Figure 8. Access Road to Pal Beach (source: persona documentation)

In February 2014, at the beginning when Pal beach began to be known by the people of North Sulawesi, the number of visitors who came reached 5000 people in every holiday [7]. However, due to the damaged access road, the numbers of visitors drastically decreased to only about 300 visitors. The decline in the number of visitors also given the economic impact on society who trade in the tourist area around the Pal beach. In the peak season, income of the people can reach Rp. 7 million per day, but has decreased to Rp. 300 thousand per day. This problem is particularly regrettable by the community.

\section{Parking and Other Supporting Facilities}

Pal beach area has a spacious parking area so that the visitors do not need to wonder around to get a parking spot as shown in the Figure 9. In Pal coastal resort, there are a number of gazebo with three sizes: large, medium and small built by the government of North Minahasa Regency. This gazebos (Fig. 10), besides used as a family resting place, is also used for Christians worship places who do beach tourism worship. Gazebos for rent with various prices, as in Table 2.

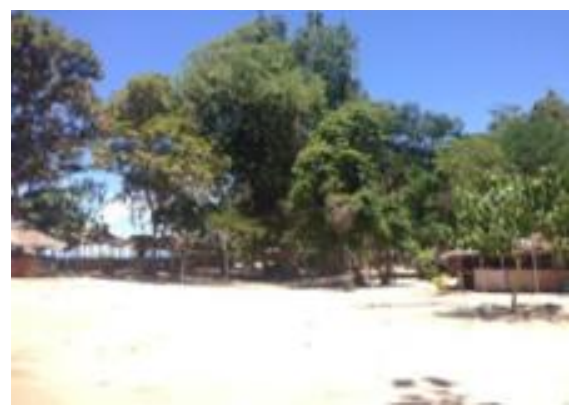

Figure 9. Parking Area in Pal Beach (source: personal documentation)
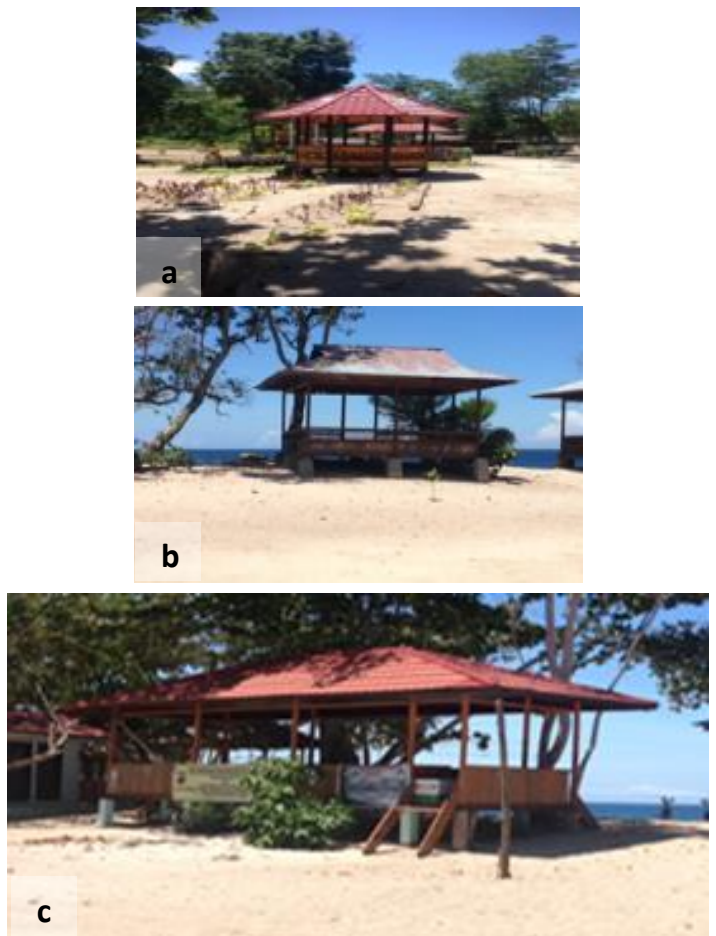

Figure 10. Gazebo in Pal Beach. a) small gazebo, b) medium gazebo, c) large gazebo. (source: personal documentation) 
Table 2. List of Price and Total Gazebo

\begin{tabular}{cccc}
\hline No & Form & $\begin{array}{c}\text { Amount of } \\
\text { gazebo }\end{array}$ & $\begin{array}{c}\text { Price per gazebo } \\
\text { (Rupiah) }\end{array}$ \\
\hline 1 & Large & 7 & 300,000 \\
2 & Medium & 4 & 200,000 \\
3 & Small & 140 & 100,000 \\
\hline & Total & $\mathbf{1 5 1}$ & \\
\hline
\end{tabular}

Source: Village Government of Marinsouw

\section{Tourism Development of Pal Beach}

The development of a tourism object is related to the advantages of a destination that can be a tourism attraction for a visit [8]. It is seen from the offered products such as attractions, facilities, and access. These products become a magnet for tourists who create the impression that can make them revisit the area [9].

The study on the development of a superior tourism destination should be seen from 4 main aspects (4A), namely attraction, accessibility, amenity and ancilliary [4]. Attraction, related to what to see and what to do. The attractions are the beauty and uniqueness of nature, the culture of the local community [10]. Problems facing by accessibility are related to the travel distance and forest road quality.

Ijen craters have three important aspect in competitiveness tourism aspect, namely something to see (mountain landscape), something to do (trekking, hiking, bird watching), and something to buy (meals) [11]. Amenity is all the supporting facilities that can meet the needs and desires of tourists while in the tourism attractions. Amenity for tourism includes accommodation, restaurant, health infrastructure, bank and other aspects supporting tourism business. The availability of amenity instrument was important to the destination [12].

Ancilliary is the availability of an organization that can manage tourism attractions, such as making promotions, regulations and so on that can benefit the government, surrounding communities, and other stakeholders [13]. The study of coastal tourism object development, when viewed from the possessed advantages based on $4 \mathrm{~A}$ aspects above, it can be explained as follows.

\section{Accessibility (affordability)}

Accesibility is a general term used to describe the degree to which a product, devise, service, or environment is avaible to as many people as possible. It is entire transportation system comprising of routes, terminals and vehicles. To be able to get to the Pal coastal resorts, we must use a private vehicle, motorcycle or rental car. Public transportation such as buses or public transportation is not available. This is due to the access road to the Pal beach tourism attraction is damaged and rocky and the road conditions are wavy. When the rainy season, the road to get to the location will be slippery while the width of the existing road is only about $\pm 4 \mathrm{~m}$, so it would complicate the tourists especially those using cars. If two cars met in the opposite direction. it will cause congestion. Because many tourists complained about this problem, it resulted in decreasing the number of visitors to Pal beach in November 2015 and affected incomes of tourism actors around Pal beach.

Troubleshooting for Pal beach entrance is to re-increase the number of visits to the Pal beach. Thus the government must fix this by asphalting and widening the road along the way to Pal beach. Pal beach has a parking area that is wide enough so that the tourists do not get difficulty in finding a parking space.

\section{Attraction \\ Natural Attraction}

Naturally, Pal beach can display a view of the beautiful beaches with charming white sand. Pal coast has cool natural climate, with tiny turtles out of the white sand as a natural attraction that makes a uniqueness to the coastal resort. Mangrove plants which are located around the coast also make Pal beach increasingly rich in natural beauty.

\section{Cultural Attraction}

Marinsouw rural communities is a mix of Sangihe, Talaud, Gorontalo and Minahasa Tribes that rich with cultural and religious attractions. They also has a very strong majority embrace in Christianity. The art cultural festival is annually conducted on January $31^{\text {st }}$ called Kunci Taon which means closing the series of events and events in the previous year, in the form of Tulude religious tradition. Tulude tradition displayed Masamper dance that symbolizes fellowship and worship to God. Masamper is a dance that is accompanied with Christian hymns. Masamper dance performed by men in a group consisting of 15-20 persons. With a chorus paired with dance movements, it makes Masamper interesting to be seen. Every August $18^{\text {th }}$, they celebrate anniversary of the village by conducting Masamper festival. Besides Masamper dance, Ampa Wayer dance is a typical dance of Sangihe tribe which also performed. 
Marinsouw village's indigenous culture is not yet packed in a travel package as religious promotion to attract more foreign domestic tourists to come to Marinsouw village and Pal beach. Tulude culture package with professional management were expected to increase the local revenue and support the local economies [14].

\section{Special Types of Attraction}

Special attractions such as cultural stage and arts stage performances do not exist in Pal coastal areas because of lack of resources to design the attractions of tourism as part of a package that can be promoted. The average level of education in Marinsouw Village is dominated by high school graduates (158 persons) followed by university graduate (13 persons). There is a need for cooperation with the regency government to bring in professionals for providing education or training to the youth to manage cultural arts of Marinsouw village as one of the Pal coastal tourism attractions. The performance of the show should be supported by wellorganized stage management, from before until after the show [15].

\section{Amenities (facilities/comfort) Accommodation}

Pal beach tourism area did not have perfect base such as hotels or cottages. The distance between Pal beach and Manado as a gateway to North Sulawesi tourism is $57.4 \mathrm{~km}$ and takes about 1 hour 31 minutes. This emphasize that the development of coastal tourism should be supported by an adequate accommodation facilities for tourists who want to stay in a few days to enjoy the beauty of Pal beach. The government also needs to attract investors to build hotels in the tourism area of Pal beach. Provision of adequate accommodation facilities makes Pal beach attraction have a high sale value and promotion in order to give economic benefits for the rural life of communities of Marinsouw, and increase the people's living standards and job opportunities. In addition to hotels, home residents can also be used as a homestay for tourists, which if managed properly will improve the welfare of local communities. homestay can be a new business opportunity for local residents [16].

\section{Restaurant}

Pal beach tourist area needs permanent restaurants as a supporting tourism facility. The restaurants need to be located based on the group of Tourism Region Unit. A unit of the tourist area is an area that has centers of tourist activities and has a circuit connection or travel lane. The stall that used as a place to sell food now has no uniqueness and appeal for tourists to eat. The tendency of local tourists visiting the beach to bring their own food and to be enjoyed in rented gazebos. The food is sold only in the form of snacks and traditional snacks such as fried bananas, fried sweet potatoes and so forth. The uniqueness of coastal restaurants model can be used as a destination tourism destination [17].

\section{Water and sanitation}

In the development of Pal beach tourism, availability of sanitation such as clean water and sanitation, and also public toilets should be constructed and organized by tourism standards. The public toilets are permanently built for the convenience of visitors as users. There should be a drilled well at certain point as a place to take clean water for sanitation needs in Pal coastal resort so that the process of sanitation and waste disposal can be managed and well ordered. The development of a tourism attraction needs water sources that will be used to support tourism activities [18].

\section{Trash can}

Although Pal beach area provide 120 bins that were distributed in various places, the trash bins does not separate the plastic waste, dry waste, and the restaurants waste. In Pal coastal tourism development, the trash bins need to be managed properly by providing bins for plastic, dry waste and food waste with a label so that visitors will throw the garbage in the correct type of waste. Waste that is not managed properly will cause environmental pollution impact and affect the cleanliness and comfort of the tourism area. The waste management system in the tourism area becomes very important to manage the waste management generated around the tourism sites. Waste management covers the management of organic waste and inorganic waste. Organic waste management can be done through composting for trees around tourist areas and utilization of waste as biogas for the driving of creative industries. Inorganic waste management can be done through recycling waste into products with higher value, such as handicrafts or other similar products [19].

\section{Souvenir Sales}

Pal beach area needs to build souvenir shop that provide handicraft and typical food of local community to take home as souvenirs. Stalls 
must be arranged in units of the tourism area so visitors can easily get souvenirs.

\section{Sport tourism}

Pal beach features sports tourism such as banana boat and donut boat. In this cases the need for additional recreational facilities that are more creative and challenging as selling points that can be promoted for coastal tourism destinations. Although tourism sport is only a supporting facilities for the tourism, but it can be something interesting and greatly demanded when its availability is managed properly. Good management and development of marine and coastal-based sport tourism could made a significant contribution to both tourism and sport development for the region [20].

\section{ATM facility}

In the development of Pal coastal resorts there is a need to provide financial facilities such as ATM that was built next to the restaurant and guarded. This includes important facilities for visitors who do not take cash when visiting Pal coast, while the activities of tourism include buying and selling in Pal coastal resorts.

\section{Health facility}

Health facilities are also needed in the development of Pal coastal resorts. Based on the existing data of health facilities, there only one health center in Marinsouw village with one doctor. There is also a posyandu (integrated service center) managed by Marinsouw village community. Health facility was provided to support community needs to meet basic health standard and diseases problems. It includes city hospitality, public health service in each district (Village Health Center, Village Health Sub-Center, and Village Health Post), and drug store. However, the facility can also be used to support amenity for tourism development by improving standard services in some aspects [12].

\section{Ancillary Services (Institutional Services and Promotions) \\ Marketing information systems and tourism promotion}

Pal coastal tourism areas does not have the information and telecommunication systems on tourism. Pal beach tourism promotion is done through words of mouth from visitors who came and enjoy the beauty of Pal beach. Visitor documentation contained in their social media accounts and also through the mass media.

The government needs to make the structuring and development of tourism information systems effectively and comprehensively as one of the market access at home and abroad to promote the Pal beach. Developing a joint pattern promotion between regions and with tourism business, join tourism promotion events at the international, national, regional levels, and organizing promotional activities such as festivals are several programs that can be conducted to promote Pal Beach. Promotion is one of the most effective marketing elements for tourism product. The objectives of promotion which are consistent with the general marketing plan is to identify the target group to which the promotion is conducted, to find out the effective advertising, sales support and public relations programs to be planned, and to select the best methods to be used to control and assess the promotion implementation [21]. Every destination country should extend its efforts to discover the needs and follows necessary promotional strategies to raise interest among the potential tourists. It is very important for the decision makers to understand how customers acquire information especially for tourism related services and products [22].

\section{Government policy}

Government Work Plan of North Minahasa Regency in 2015 set the theme: continuing the acceleration of infrastructure supporting tourism, food security, economic democracy, and the conservation of natural resources [6]. Based on this plan, then tourism becomes one of the central development of North Minahasa District. This is the key to the development of attractions including Pal beaches.

\section{Recommendation \\ North Minahasa Regency Tourism Office}

North Minahasa Regency Government through the Department of Tourism and Cultural needs to make an MoU with BUMN as the StateOwned Enterprises to build Pal beach attraction. It is a pity if the potential of Pal beach is not developed and promoted as a tourism destination area. It necessary to restructure and mapping the Pal coastal tourism area unit. It is also crucial to attract investors to build tourism supporting facilities such as accommodation, tourism information center, souvenir shops, special attraction. The Pal Beach management should provide professional human resources in the field of hospitality and tourism attractions to manage Pal beach. Lastly, they need to increase counseling and training in preparing resources for the development of Pal beach tourism object. 


\section{Marinsouw Rural Community}

Marinsouw community need to preserve their cultural customs, such as Tulude as a tourism attraction to be promoted. We also suggest to make Masamper dance attractions on certain days in Pal coastal resort. The community should manage local products such as Goroho banana chips, cassava chips, and skills for making plastic flower stalks as typical souvenir from Marinsouw village to raise the family economy. It is also important to raise awareness in maintaining the security and cleanliness of Pal coastal resorts.

\section{CONCLUSION}

Based on the results of the study on the development of coastal tourism object, it can be concluded that Accessibility (affordability) to Pal coastal resort needs to be repaired by resurfacing and widening the road. Attraction (points) in this culture, e.g. religious tourist attraction such as Tulude needs to be developed and packaged in an attractive way so that attract more domestic or foreign tourists to come to Marinsouw village and Pal beach. Pal coastal area need to build an inn or cottage accommodation in Pal coastal region. It is also necessary to hold art and culture of Marinsouw rural communities, souvenir shops, restaurants, public toilets, and additional recreation attraction for entertainment. For the ancillary services, there is a need to make marketing and promotional information systems of Pal beach tourism with the full support from the Government in promoting Pal beach attraction. It is expected that the local governement cooperate with State-Owned Enterprises (BUMN) for the development of Pal beach tourism object.

\section{REFERENCES}

[1] Statistic Center of North Sulawesi Utara. Tourism Development in North Sulawesi. Available at: sulut.bps.go.id/new/backend 2/brsind/brsInd-20161003164730.pdf.

[2] Yoeti, O. A. 1985. Pengantar ilmu pariwisata. PT Pradnya Paramita. Jakarta.

[3] Miles, M. B. and A. M. Huberman. 1992. Qualitative data analysis: sourcebook of new methods. Rohidi, T.R. (Transl). University of Indonesia. Jakarta.

[4] Cooper, C., J. Fletcher, D. Gilbert, R. Shepherd and S. Wanhill, 1993. Tourism principles and practice model. Addison Wesley Longman Limited. England.
[5] Telusur Indonesia. 2015. Pal beach tourism. Available at: http://www.telusurindonesia. com.

[6] Work Plans of Regional Development North MInahasa. 2015. Government Work Plan of North Minahasa Regency in 2015. North Minahasa Regency.

[7] Gabriel, T. 2016. Village Head of Marinsou, East Likupang District, North Minahasa Regency. Personal Communication.

[8] Indonesian Culture and Tourism Department. 2015. General planning and tourism area development. Available at: http://www.indonesiacultureandtourism.co $\mathrm{m} / 2015 / 11 /$ perencanaan-danpengembangan-kawasan.html.

[9] Asinar, R. S. Kenapa wisatawan ingin ke Indonesia? 2015. Kompasiana. Available at: https://www.kompasiana.com/syam/kenap a-wisatawan-ingin-keindonesia_54f36c79745513992b6c7539.

[10] Attar, M., L. Hakim and B. Yanuwiadi. 2013. Analisis potensi dan arahan strategi kebijakan pengembangan desa ekowisata di Kecamatan Bumiaji. Journal of Indonesian Tourism and Development Studies 1(2), 6878.

[11] Putri, S. D., Soemarno and L. Hakim. 2015. Strategic management of nature-based tourism in ljen Crater in the context of sustainable tourism development. Journal of Indonesian Tourism and Development Studies 3(3), 123-129.

[12] Normelani, E. 2017. The potentiality of tourism resources in Hulu Sungai Selatan Regency, South Kalimantan. Journal of Indonesian Tourism and Development Studies 5(1), 1-8.

[13] Butarbutar, R. R. and Soemarno. 2013. Pengaruh aktivitas wisatawan terhadap keanekaragaman tumbuhan di Sulawesi. Journal of Indonesian Tourism and Development Studies 1(2), 87-96.

[14] Gunawan, A. S., D. Hamid and M. G. W. Endang N.P. 2016. Analisis pengaruh pengembang-an pariwisata terhadap sosial ekonomi masyarakat (studi pada wisata religi Gereja Puhsarang Kediri). Jurnal Administrasi Bisnis 32(1), 1-8.

[15] Haryudi, R. 2015. Kepemimpinan Stage Manager dalam manajemen panggung pertunjukkan. NARADA, Jurnal Desain dan Seni, FDSK-UMB 2(1), 77-94.

[16] Khairina, D. F. and M. Rahdriawan. 2014. Homestay sebagai usaha pengembangan 
Desa Wisata Kandri. Jurnal Teknik PWK 3(4), 1060-1071.

[17] Isa, W. Pengembangan sarana dan prasarana daya tarik wisata. InspirasiEdukasi. Available at: cvinspireconsulting.com.

[18] Khairun, N. and J. Arthani. 2011. Kualitas air dan persepsi wisatawan di Kawasan Alam Pulau Pinus Kalimantan Selatan. Jurnal Hutan Tropis 12(31), 26-36.

[19] Dewi, R. P. 2017. Perancangan sistem pengelolaan sampah untuk mendukung perkembangan industri kreatif di daerah pariwisata. Proceeding of National Seminar on Multi-disciplinary Studies and $3^{\text {rd }}$ Call For Papers Unisbank (Sendi_U 3). 217-221.

[20] Lagarense, B. E. S. and A. Walansendow. 2016. Developing marine and coastal-based sport tourism on the waterfront: the case of Manado Waterfront, Indonesia. Journal of Indonesian Tourism and Development Studies 4(3), 107-114.

[21] Baldemoro, J. 2013. Tourism promotion. Slideshare. Available at: http://www.slide share.net/JHBlue/tourism-promotion28432196.

[22] Abul, H. M. 2015. Promotional activities in the strategic tourism development of Lapland case study: tour operator's appearance in social media. Thesis. Applied Sciences Programme Degree in Tourism. Centria University. Available at: https:// www.theseus.fi/bitstream/handle/10024/9 6778/Final\%20thesis\%20Hasan\%202.pdf?se quence $=1$. 